\title{
PENGARUH KEGIATAN MUHADATSAH TERHADAP KARAKTER KOMUNIKATIF SANTRI MADRASAH ALIYAH DI PONDOK PESANTREN NURUL FALAH
}

\author{
Puji Rahayu $^{1}$, Rusydi Sulaiman ${ }^{2}$ Dian Puspita Eka Puti ${ }^{3}$ \\ ${ }^{1,2,3}$ IAIN Syaikh Abdurrahman Siddik Bangka Belitung
}

Info Artikel :

Diterima 29 Juli, 2021

Direvisi 27 Agustus, 2021

\section{Kata Kunci:}

Kegiatan Muhadatsah

Karakter Komunikatif

Santri

\section{Koresponden:}

Puji Rahayu,

Email: pujirhy398@gmail.com

\begin{abstract}
ABSTRAK
Diambilnya permasalahan ini berdasarkan pertimbangan bahwa saat ini dibutuhkan upaya untuk mengembangkan karakter komunikatif pada setiap santri. Dalam mengembangkan karakter komunikatif, dibutuhkan beragam aktivitas dengan melibatkan beberapa orang bahkan kelompok agar saling berkomunikasi dan bekerjasama. Mengingat adanya kegiatan muhadatsah di Pondok Pesantren Nurul Falah, seharusnya kegiatan tersebut dijadikan sarana latihan untuk masing-masing santri dalam mengembangkan karakter komunikatif dalam dirinya sehingga mampu mempengaruhi dalam keseharian setiap santri. Penelitian ini bertujuan untuk mengetahui ada atau tidaknya pengaruh yang signifikan pada kegiatan muhadatsah terhadap karakter komunikatif santri Madrasah Aliyah di Pondok Pesantren Nurul Falah.

Penelitian ini dilaksanakan di Pondok Pesantren Nurul Falah pada semester genap tahun ajaran 2020/2021. Metode yang dilakukan pada penelitian ini adalah kuantitatif asosiatif yang bertujuan untuk mengungkapkan dan menjelaskan atar satu variabel dengan variabel lainnya. Teknik pengambilan data pada penelitian ini adalah angket. Sedangkan instrumen pada penelitian ini adalah uji validitas dan reliabilitas. Teknik analisis data menggunakan uji regresi linear sederhana.

Adapun hasil dari penelitian ini menyatakan bahwa terdapat pengaruh yang signifikan pada kegiatan muhadatsah terhadap karakter komunikatif santri Madrasah Aliyah di Pondok Pesantren Nurul Falah. Hasil penelitian ini menunjukkan bahwa nilai signifikansi sebesar 0,000. Artinya $0,000<0,05$, maka dapat dikatakan bahwa variabel $\mathrm{X}$ (muhadatsah) berpengaruh pada variabel $\mathrm{Y}$ (karakter komunikatif). Sedangkan nilai $\mathrm{T}$ hitung sebesar 4,159 dan $\mathrm{T}$ tabel sebesar 1,676 yang berarti $\mathrm{T}$ hitung $>\mathrm{T}$ tabel. Kemudian pada uji $\mathrm{R}$ square $0,261 \times 100=26,1 \%$. Jadi, variabel $\mathrm{X}$ (muhadatsah) mempengaruhi variabel Y (karakter komunikatif) sebesar $26,1 \%$.
\end{abstract}

\section{Pendahuluan}

Pada saat ini, perkembangan remaja terlihat maju mundur dalam beriman dan bertakwa kepada Tuhan yang maha Esa, karena remaja sangat mudah dipengaruhi oleh keadaan lingkungan sekitar. Oleh karena itu, antara keluarga, sekolah dan masyarakat harus ikut berperan dalam upaya mencetak sumber daya manusia yang berkualitas dan berkarakter, karena karakter berawal dari sebuah kebiasaan. ${ }^{1}$ Suatu upaya dalam mengembangkan karakter peserta didik yaitu dengan adanya pendidikan karakter di sekolah.

Pendidikan karakter merupakan usaha dalam penanaman kecerdasan dalam berpikir, penghayatan dalam bersikap, dan pengamalan dalam berperilaku sesuai nilai-nilai luhur yang menjadi identitasnya, yang diaktualisasikan ketika berinteraksi dengan Tuhan, diri sendiri dan orang lain atau masyarakat. Dalam menanamkan pendidikan karakter tidak bisa hanya dengan mentransfer ilmu saja, tetapi harus ada

\footnotetext{
${ }^{1}$ Abdulloh Hamid, Pendidikan Karakter Berbasis Pesantren, (Surabaya: IMTIYAZ, 2017), hlm. 1-2.
} 
proses, teladan dan pembiasaan dalam lingkungan peserta didik. ${ }^{2}$ Salah satu karakter penting yang harus ditanamkan yaitu karakter komunikatif. Karakter komunikatif merupakan karakter yang dapat membawa seseorang untuk membangun hubungan baik antar individu tanpa melihat latar belakang seperti ras, suku, agama, asal daerah atau latar belakang lainnya. Manusia adalah makhluk sosial, artinya ia harus memiliki kemampuan berkomunikasi secara baik agar bisa menjalin hubungan baik dengan orang lain. Untuk memiliki kemampuan komunikasi yang baik harus diawali dengan banyak latihan berbicara baik secara individu maupun berkelompok.

Seperti di Pondok Pesantren Nurul Falah yang memiliki berbagai kegiatan, salah satunya yaitu kegiatan muhadatsah. Kegiatan Muhadatsah merupakan kegiatan seseorang dalam bercakap-cakap menggunakan bahasa Arab. Kegiatan muhadatsah dijadikan sebagai upaya untuk memudahkan santri berkomunikasi dan mengembangkan karakter komunikatif santri. Pada kenyataannya tidak semua santri dapat berkomunikasi dengan baik, terlebih dihadapan umum. Masih terdapat santri yang takut, tidak percaya diri ketika mendapatkan giliran untuk tampil dihadapan teman-temannya. Artinya, sebagian santri ada yang belum mampu untuk mengembangkan karakter komunikatif pada diri mereka. Bahkan tidak semua santri disiplin dalam mengikuti kegiatan muhadatsah. Ada yang berpura-pura sakit agar mereka tidak mengikuti kegiatan muhadatsah dikarenakan takut dan tidak percaya diri. Padahal dengan adanya kegiatan muhadatsah, setiap santri dilatih untuk berbicara yang memberikan tingkat kepercayaan diri dalam berkomunikasi, sekaligus berbicara menggunakan bahasa Arab. Seharusnya seluruh santri giat mengikuti kegiatan muhadatsah yang telah diprogramkan pihak Pesantren, sehingga apa yang diharapkan untuk mengembangkan karakter komunikatif dapat tercapai.

Sebagaimana pemaparan di atas, penulis tertarik untuk mengkaji secara lebih dalam mengenai pengaruh kegiatan muhadatsah terhadap karakter komunikatif santri. Oleh karena itu, penelitian ini ingin melihat apakah kegiatan muhadatsah berpengaruh terhadap karakter komunikatif santri dengan mengambil judul "Pengaruh kegiatan muhadatsah terhadap karakter komunikatif santri Madrasah Aliyah di Pondok Pesantren Nurul Falah".

\section{Metode}

Penelitian ini merupakan penelitian kuantitatif asosiatif. Penelitian kuantitaif asosiatif merupakan penelitian yang dilakukan untuk mencari dan menganalisis hubungan atau pengaruh antarsatu variabel dengan variabel lain. metode yang digunakan dalam penelitian ini yaitu metode survey. Penelitian ini dilakukan di MA Pondok Pesantren Nurul Falah yang beralamat di J1. Pangkol, Desa Air Mesu, Kecamatan Pangkalan Baru, Kabupaten Bangka Tengah pada semester genap tahun ajaran 2020/2021. Populasi dalam penelitian ini adalah seluruh santri kelas XI MA Nurul Falah dengan jumlah 104 santri. Metode yang digunakan dalam pengambilan sampel yaitu teknik probability sampling bagian proportionate stratified random sampling dengan rumus Taro Yamane, sehingga mendapatkan sampel dengan jumlah 51 santri.

Metode pengumpulan data dalam penelitian ini melalui kuesioner atau angket dan dokumentasi. Instrumen pengumpulan data yang digunakan berupa angketatau pernyataan yang diberikan kepada santri, untuk memperoleh data dari variabel bebas dan variabel terikat. Sebagai variabel bebas adalah kegiatan muhadatsah (X), sedangkan variabel terikat (Y) adalah karakter komunikatif santri.

Sebelum memberikan angket kepada subjek penelitian yaitu 51 santri MA kelas XI di Pondok Pesantern Nurul Falah, dilakukannya uji validitas yang dilakukan kepada 30 santri kelas XI MA Al-Islam Kemuja. Uji validitas dalam penelitian ini menggunakan rumus Product moment correlation, kemudian untuk uji reliabilitas menggunakan rumus cronbach alpha. Setelah melakukan uji validitas instrumen, terdapat item-item angket yang valid dan tidak valid. Item valid itulah yang digunakan untuk angket penelitian santri XI MA Nurul Falah dengan jumlah 51 santri.

Adapun analisis data dalam penelitian ini akan dilakukan uji prasyarat terlebih dahulu. Pengujian prasyarat analisis data melalui uji normalitas, uji linearitas dan uji heteroskedastisitas. Setelah melakukan uji prasyarat, maka dilakukan uji regresi linear sederhana untuk mengetahui hipotesis dan menguji sejauh mana hubungan antara kegiatan muhadatsah terhadap karakter komunikatif santri MA di Pondok

\footnotetext{
${ }^{2}$ Zubaedi, Desain Pendidikan Karakter: Konsepsi dan Aplikasinya dalam Lembaga Pendidikan, (Jakarta: Kencana, 2011), hlm. 17.
} 
Pesantren Nurul Falah. Pengujian dalam penelitian ini, dilakukan dengan bantuan program SPSS versi 16.0.

\section{Hasil dan Pembahasan}

Penelitian ini terdiri dari beberapa tahap, tahap pertama yaitu pengujian instrumen dengan uji validitas instrumen dan uji reliabilitas instrumen. Tahap kedua yaitu uji prasyarat analisis dengan melakukan uji normalitas, linearitas, dan heteroskedastisitas. Tahap ketiga yaitu analisis data dengan uji regresi linear sederhana.

Tahap pertama yaitu uji validitas, diketahui terdapat 29 item yang valid pada variabel X (kegiatan muhadatsah) dan 30 item valid pada varibel Y (Karakter komunikatif). Kemudian untuk uji reliabilitas, diketahui instrumen kegiatan muhadatsah dikatakan reliabel sempurna dengan cronbach alpha 0,914 $>0,60$ dan instrumen karakter komunikatif dikatakan reliabel sempurna dengan cronbach alpha 0,885 > 0,60.

Tahap kedua yaitu uji persyaratan analisis data melalui : 1) uji normalitas yang menunjukkan hasil berdisitribusi normal dengan nilai signifikan $0,965>0,05,2)$ uji linearitas menunjukkan hasil yang linear dengan nilai signifikan $0,100>0,05,3$ ) uji heteroskedastisitas menunjukkan hasil tidak terdapat gejala heteroskedastistas dengan nilai signifikan 0,400 $>0,05$.

Kemudian tahap ketiga yaitu uji regresi linear sederhana yang digunakan untuk menguji hipotesis penelitian. Hipotesis yang dirumuskan dalam penelitian ini yaitu terdapat pengaruh yang signifikan kegiatan muhadatsah terhadap karakter komunikatif santri Madrasah Aliyah di Pondok Pesantren Nurul Falah. Adapun untuk mengetahui uji hipotesis dalam penelitian ini sebagai berikut:

\section{Model Summary}

\begin{tabular}{|c|c|c|c|c|}
\hline Model & $\mathrm{R}$ & $\mathrm{R}$ Square & $\begin{array}{c}\text { Adjusted R } \\
\text { Square }\end{array}$ & $\begin{array}{c}\text { Std. Error of the } \\
\text { Estimate }\end{array}$ \\
\hline 1 & $.511^{\mathrm{a}}$ & .261 & .246 & 10.45864 \\
\hline
\end{tabular}

a. Predictors: (Constant), Kegiatan Muhadatsah

Tabel di atas menunjukkan hasil uji $\mathrm{R}$, yang mengukur seberapa jauh kemampuan model dalam menerangkan variasi variabel dependen atau variabel $\mathrm{X}$. Diketahui $\mathrm{R}$ square atau koefisien determinasi sebesar 0,261.

Kemudian untuk hasil uji regresi linear sederhana sebagai berikut:

\begin{tabular}{|c|c|c|c|c|c|}
\hline \multicolumn{6}{|c|}{ Coefficients $^{\mathrm{a}}$} \\
\hline \multirow[b]{2}{*}{ Model } & \multicolumn{2}{|c|}{$\begin{array}{l}\text { Unstandardized } \\
\text { Coefficients }\end{array}$} & \multirow{2}{*}{\begin{tabular}{|c}
$\begin{array}{c}\text { Standardize } \\
\mathrm{d} \\
\text { Coefficients }\end{array}$ \\
Beta
\end{tabular}} & \multirow[b]{2}{*}{$\mathrm{t}$} & \multirow[b]{2}{*}{ Sig. } \\
\hline & B & $\begin{array}{l}\text { Std. } \\
\text { Error }\end{array}$ & & & \\
\hline 1 (Constant) & 60.481 & 14.063 & & 4.301 & .000 \\
\hline $\begin{array}{l}\text { Kegiatan } \\
\text { Muhadatsah }\end{array}$ & .554 & .133 & .511 & 4.159 & .000 \\
\hline
\end{tabular}

a. Dependent Variable: Karakter

Komunikatif

Diketahui apabila nilai signifikan $0,000<0,05$ dan nilai t hitung $>\mathrm{t}$ tabel maka dapat dikatakan terdapat pengaruh. Dari tabel di atas, nilai signifikan dari uji regresi kegiatan muhadatsah terhadap karakter komunikatif santri Madrasah Aliyah di Pondok Pesantren Nurul Falah sebesar 0,000 < 0,05 dan t hitung $4,159>1,676$. Kemudian, hasil output di atas menunjukkan bahwa nilai constant sebesar 60.481, sedangkan nilai koefisien regresi sebesar 0,554. Dengan persamaan sebagai berikut:

$\mathbf{Y}=\mathbf{a}+\mathbf{b} \mathbf{X}$

$=60.481+0,554 \mathrm{X}$

Dari nilai persamaan tersebut, menyatakan bahwa koefisien regresi tersebut bernilai positif, sehingga dapat dikatakan bahwa pengaruh variabel kegiatan muhadatsah terhadap karakter komunikatif santri adalah positif. Serta menyatakan bahwa setiap penambahan $1 \%$ nilai kegiatan muhadatsah, maka nilai karakter komunikatif bertambah sebesar 0.554 . 
Berdasarkan pengujian yang telah dilakukan di atas, dapat diketahui hasilnya bahwa terdapat pengaruh yang signifikan kegiatan muhadatsah terhadap karakter komunikatif santri Madrasah Aliyah di Pondok Pesantern Nurul Falah. Kegiatan muhadatsah dapat mempengaruhi karakter komunikatif sebesar 26,1\% dan sisanya 73,9\% dipengaruhi oleh faktor lain. Kemudian, pengaruh variabel kegiatan muhadatsah terhadap karakter komunikatif santri adalah positif. Serta menyatakan bahwa setiap penambahan 1\% nilai kegiatan muhadatsah, maka nilai karakter komunikatif bertambah sebesar 0.554.

\section{Kesimpulan}

Berdasarkan hasil penelitian yang telah dilakukan peneliti di Pondok Pesantren Nurul Falah tentang pengaruh kegiatan muhadatsah terhadap karakter komunikatif santri, diperoleh kesimpulan bahwa: Kegiatan muhadatsah mempunyai pengaruh yang signifikan kegiatan muhadatsah terhadap karakter komunikatif santri Madrasah Aliyah di Pondok Pesantren Nurul Falah sebesar 26,1\% dan sisanya 73,9\% dipengaruhi oleh faktor lain. Hal ini dibuktikan dengan nilai signifikansi 0,000<0,05 dan t hitung 4,159> 1,676. Kemudian, pengaruh variabel kegiatan muhadatsah terhadap karakter komunikatif santri adalah positif. Serta menyatakan bahwa setiap penambahan $1 \%$ nilai kegiatan muhadatsah, maka nilai karakter komunikatif bertambah sebesar 0.554 .

\section{Referensi}

Aeni, Ani Nur. 2014. Pendidikan Karakter untuk Mahasiswa PGSD. Bandung: UPI PRESS

Izzan, Ahmad. 2009. Metodologi Pembelajaran Bahasa Arab. Bandung: Humainora

Hamid, Abdulloh. 2017. Pendidikan Karakter Berbasis Pesantren. Surabaya: IMTIYAZ

Noor, Juliansyah. 2017. Metodologi Penelitian: Skripsi, Tesis, Disertasi \& Karya Ilmiah. Jakarta: Kencana

Sugiyono. 2015. Metode Penelitian Pendidikan Pendekatan Kuantitatif dan Kualitatif, dan R\&D. Bandung: Alfabeta

Zubaedi. 2011. Desain Pendidikan Karakter: Konsepsi dan Aplikasinya dalam Lembaga Pendidikan. Jakarta:

Kencana 